\title{
Pszichogén nem epilepsziás rosszullétek a klinikai gyakorlatban
}

\author{
Szita Bernadett ${ }^{1}$ - Hidasi Zoltán dr. ${ }^{2}$ \\ Semmelweis Egyetem, Általános Orvostudományi Kar, ${ }^{1}$ I. Szülészeti és Nőgyógyászati Klinika, \\ ${ }^{2}$ Pszichiátriai és Pszichoterápiás Klinika, Budapest
}

\begin{abstract}
A pszichogén, nem epilepsziás roham a pszichiátria és neurológia határterületén lévő, nehezen behatárolható tünetegyüttes, amely tünetmintázatában hasonlít az epilepsziára, de azt nem epilepsziás aktivitás váltja ki. Jellemzően fiatal felnőttkorban alakul ki, a betegek körében a nők aránya jóval magasabb. A pszichogén, nem epilepsziás roham diagnosztikája elsősorban video-elektroencefalográfiás vizsgálattal történhet, amely az esetek 90\%-ában a helyes diagnózis megállapításához vezethet. A kórképet mégis gyakran diagnosztizálják tévesen epilepsziának, és kezelik évekig ennek megfelelően, ami a betegekre és az egészségügyi ellátórendszerre egyaránt nagy terhet ró. A kórkép etiológiájában - az anamnézisben szereplő traumatikus életesemények gyakorisága miatt - kiemelt szerepet tulajdonítanak a pszichológiai faktoroknak. Emellett a pszichogén nem epilepsziás roham kialakulásában neurobiológiai tényezők is közrejátszanak, amelyre a betegek egy részénél talált kognitív, strukturális és funkcionális agyi eltérések utalnak. A kezelés pszichoszociális - elsősorban kognitív viselkedésterápiás - intervenciókat és kiegészítő farmakoterápiát foglal magába. A tanulmányban a szerzők a pszichogén nem epilepsziás roham tünettanával, diagnosztikájával, etiológiájával és kezelésével kapcsolatos irodalmat és az újabb kutatási eredményeket tekintik át. Orv. Hetil., 2016, 157(20), 767-775.
\end{abstract}

Kulcsszavak: pszichogén nem epilepsziás roham, video-EEG, szemiológia, etiológia, kezelés

\section{Psychogenic nonepileptic seizures: overview and implications for practice}

Psychogenic nonepileptic seizures are enigmatic disorders at the interface of neurology and psychiatry. Seizures resemble epileptic seizures but are not associated with electrical discharges in the brain. Symptoms typically start in early adulthood and women are far more affected than men. Video-EEG is widely considered to be the gold standard for diagnosis. Still psychogenic nonepileptic seizures are often misdiagnosed and treated as epilepsy for years that is burdensome to patients and costly to the healthcare system. Patients having psychogenic nonepileptic seizures show a high prevalence of traumatic life events, therefore, psychosocial factors are thought to play an important role in the etiology. Neurobiological factors may also contribute to the development of seizures as a subgroup of patients are characterized by cognitive impairment and subtle structural and functional brain abnormalities. Treatment includes psychotherapeutic procedures, particularly cognitive behavioral therapy and additional pharmacological interventions. This article presents an overview of the clinical context, diagnosis, etiology and treatment of psychogenic nonepileptic seizures.

Keywords: psychogenic nonepileptic seizures, video-EEG, semiology, etiology, treatment

Szita, B., Hidasi, Z. [Psychogenic nonepileptic seizures: overview and implications for practice]. Orv. Hetil., 2016, $157(20), 767-775$.

(Beérkezett: 2016. február 19.; elfogadva: 2016. március 17.)

\begin{abstract}
Rövidítések
CBT = kognitív viselkedésterápia; EMG = elektromiográfia; MMPI = Minnesota Multiphasic Personality Inventory; PNER = pszichogén nem epilepsziás roham; PTSD = poszttraumás stressz zavar; SISCOM = Subtraction Ictal SPECT Co-registered to MRI; SSRI = (selective serotonin reuptake inhibitor $)$ szelektív szerotonin-visszavételt gátló; TCI = Temperament and Character Inventory; TIA = átmeneti ischaemiás attak
\end{abstract}

A pszichogén nem epilepsziás roham (PNER) olyan paroxysmalisan jelentkező változás a viselkedésben vagy tudati szintben, amely az epilepsziás rohamokra hasonlító motoros, szenzoros és kognitív tünetekkel jár, ugyanakkor azt nem epilepsziás aktivitás váltja ki [1,2]. Az epilepsziás rohamokkal ellentétben, amelyek hátterében az agyi neuronok excesszív hiperszinkron kisülése áll, 
a PNER kialakulásában döntően pszichológiai okokat feltételeznek [1].

A pszichogén nem epilepsziás rohamok terminológiai és etiológiai kérdéseinek megítélése sokat változott az idők során. A rohamok kialakulása és a gyermekkori szexuális bántalmazás között feltételezett összefüggésekre már ókori forrásokat is találunk [3]. A középkori Európában a görcsöket, rohamokat vallásos jelentéssel ruházták fel. A PNER az orvosi érdeklődés középpontjába elsőként a XIX. században került, amikor a kor népszerú kórképével, a hisztériával hozták összefüggésbe, kezelésében a hipnózist szorgalmazták [3]. Freud a szexuális késztetések, elsősorban az ödipális fantáziák elfojtását vélte a tünetképzés okának [4]. A PNER mögött meghúzódó patomechanizmusok vizsgálatában a '80-as, '90es években ismét a traumatizáció került fókuszba, mivel több kutatási eredmény is igazolta a tünetképzés és az élettörténetben szereplő kritikus életesemények közti együtt járást [5]. A hisztéria megnevezés pedig a hozzá társuló pejoratív konnotáció miatt fokozatosan eltû́nt az orvosi terminológiából. Az elmúlt évtizedben a neuropszichológiai, strukturális és funkcionális agyi eltérések vizsgálata került a szakmai érdeklődés központjába.

A PNER nozológiai besorolását illetően továbbra sincs konszenzus. A 2013-ban megjelenő DSM-5 kézikönyvben a PNER a „Szomatikus tünet- és kapcsolódó zavarok” közé sorolt „Konverziós zavarok rohamokkal vagy görcsökkel” diagnosztikus kategóriának felel meg [6], míg a BNO-10 az egyéb konverziós kórképekkel együtt, disszociatív zavarként hivatkozik rájuk [7]. Mindazonáltal egyes szerzők azt is megkérdőjelezik, hogy a PNER önálló kórformának tekinthető-e, vagy inkább egy tünetnek, amely mögött a legtöbb esetben valamilyen jól definiálható pszichiátriai zavar áll [8].

\section{Epidemiológia}

A PNER előfordulása az epilepsziacentrumok ambuláns betegforgalmának 5-10\%-át, a fekvőbeteg-ellátás 2040\%-át teszi ki [9]. 100000 före eső incidenciája 1,44,9 eset évente, de a diagnosztikai nehézségek miatt a valós arány ennél minden bizonnyal magasabb $[10,11]$. Benbadis és Allen-Hauser becslései szerint a 100000 före eső prevalencia 2-33 eset évente [12].

PNER jelentkezhet (1) nem epilepsziás betegnél; (2) olyan epilepsziás betegnél, akinek az epilepsziabetegsége egyensúlyban van, így epilepsziás rohamai nincsenek, csak PNER-rosszullétei; (3) olyan epilepsziás betegnél, aki epilepszia szempontjából sem tünetmentes, így valódi epilepsziás és PNER-rosszullétei egyaránt előfordulnak [13]. Kutatások szerint a PNER és az epilepszia együttes előfordulása 5,3-73\% közé tehető $[13,14]$.

A kórkép jellemzően 15-35 éves kor között veszi kezdetét, de kisgyermekkorban és időskorban is kialakulhat $[12,15,16]$. A fiatalabb korban kezdődő PNER eseté- ben gyakoribb a betegnél vagy családtagjánál diagnosztizált epilepszia, és többször kapunk beszámolót korábbi bántalmazásról is. A felnőttkori kezdetû rohamoknál a komorbid szomatikus megbetegedések fordulnak elő nagyobb arányban [16]. A PNER-betegek körében a nók aránya jóval magasabb, egyes becslések szerint a 80\%-ot is elérheti [17]. A férfi páciensek kórtörténetében szignifikánsan kisebb arányban van jelen korábbi szexuális abúzus, komorbid pszichiátriai kórkép és krónikus fájdalom szindróma, viszont gyakrabban kapunk beszámolót munkahelyi problémákról [18].

A PNER-betegeket magas pszichiátriai komorbiditás jellemezi. A leggyakoribb komorbid pszichiátriai zavarok a depresszió (43,5-85\%), személyiségzavarok (25-67\%), poszttraumás stressz zavar (PTSD) (35-49\%), szomatoform kórképek (22-84\%) és a szorongásos zavarok (11$50 \%$ ), elsősorban pánikzavar, agorafóbia, generalizált szorongás [19].

\section{Diagnosztika}

A PNER diagnosztizálása komoly kihívást jelent mind a neurológus, mind a pszichiáter szakorvosok számára. A helyes diagnózis felállítása átlagosan 7 évet vesz igénybe, amelynek jelentős anyagi vonzata van az egészségügyi ellátórendszerre nézve, és nagy megterhelést jelent a betegek számára [20]. Differenciáldiagnosztikailag elkülönítendő kórképek az epilepszia, átmeneti ischaemiás attak (TIA), syncope (ájulás), hypoglykaemia, myasthenia gravis, paroxysmalis choreoathetosis, migrén, pánikzavar és parasomniák [21]. A diagnózis felállításának feltétele az epilepszia kizárása, amely elsősorban videoEEG-vizsgálattal történhet; a videón rögzített rohamok és a közben mért agyi elektromos aktivitás elemzése az esetek 90\%-ában a helyes diagnózis megállapításához vezet [22]. A diagnosztikát nehezíti, hogy néhány epilepsziatípus csak az esetek 10-20\%-ában jár EEG-eltéréssel [20].

\section{Provokáló technikák}

Az úgynevezett provokáló technikákat régóta használják a PNER diagnosztikájában. Az eljárás etikai kérdéseket vet fel, mivel szuggesztív technikákat alkalmaz, így egyes szerzők felvetik a páciensek megtévesztésének lehetőségét. A vizsgálat során placebót használnak, amelyről a betegek azt az információt kapják, hogy rohamokat provokálhat, a rohamokat pedig egyes esetekben szintén placebóval „állítják le” [23]. Napjainkban az epileptológusok mintegy 39-73\%-a alkalmazza a módszert, amelyek közül az intravénásan adott fiziológiás sóoldat, az alkoholos bőrtapasz, a hangvilla és a fejdöntési módszer a legelterjedtebb [23]. Benbadis szerint a következő szempontok tekinthetők a provokációs technikák indikációinak [23]: 
1. Nem jelentkeznek spontán rohamok a video-EEGmonitorozás alatt.

2. A módszer megrövidíti a diagnosztikai folyamatot, ezáltal csökkenti a kiadásokat és a várakozási időt, tehát költséghatékony.

3. Túl ritkán jelentkező rohamok.

4. A video-EEG elemzését követően sem állapítható meg egyértelmúen a diagnózis.

5. Organikus kórképeknél, ahol az epilepsziás eredet kizárásra került, de a pszichogén eredet nem bizonyított.

6. A diagnózist illetően minden kétséget kizáró bizonyosságra van szükség, például igazságügyi orvos szakértői vizsgálatok során.

Szuggesztív provokáló technikák alkalmazása során az etikai kérdések, a haszon-kockázat elemzés és az orvosbeteg kapcsolat szempontjainak együttes mérlegelése javasolt.

\section{Video-EEG-vizsgálat}

A video-EEG-monitorozás a PNER diagnosztikájában elsődlegesen alkalmazandó eljárás, amely egyidejűleg rögzíti a beteg agyi elektromos aktivitását és a közben lezajló motoros és egyéb klinikai tevékenységeket [24]. $\mathrm{Az}$ interictalis rutin-EEG-eredmények önmagukban félrevezetők lehetnek, mivel az epilepsziás betegek körülbelül 30\%-ánál nem jelentkezik EEG-eltérés, nem specifikus EEG-eltérések viszont az egészséges populáció több mint 10\%-ánál vannak jelen [24].

\section{Szemiológia}

A video-EEG során rögzítésre kerülő rohamok elemzése azért kulcsfontosságú a PNER diagnosztikájában, mert egyes ictalis szemiológiai jellemzők megjelenése jóval gyakoribb vagy ritkább, mint az epilepsziás rohamok

1. táblázat |A PNER osztályozási rendszereinek összehasonlítása

\begin{tabular}{|c|c|c|c|c|c|}
\hline $\begin{array}{l}\text { Gröppel, et al. (2000) } \\
{[27]}\end{array}$ & $\begin{array}{l}\text { Seneviratne, et al. (2010) } \\
{[28]}\end{array}$ & $\begin{array}{l}\text { Hubsch, et al. (2011) } \\
\text { [29] }\end{array}$ & $\begin{array}{l}\text { Szabó, et al. (2012) } \\
{[15]}\end{array}$ & $\begin{array}{l}\text { Dhiman, et al. (2013) } \\
{[30]}\end{array}$ & $\begin{array}{l}\text { Wadwekar, et al. (2014) } \\
\text { [31] }\end{array}$ \\
\hline \multirow[t]{4}{*}{ Pszichogén motoros } & $\begin{array}{l}\text { Hipermotoros / } \\
\text { hiperkinetikus }(3,3 \%) \\
\text { - a törzs és a végtagok } \\
\text { erőteljes } \\
\text { bilateralis, } \\
\text { aszimmetrikus, } \\
\text { aszinkron mozgása }\end{array}$ & $\begin{array}{l}\text { Hiperkinetikus } \\
\text { - elnyújtott rohamok, } \\
\text { hyperventilatio, törzs } \\
\text { és a végtagok mozgása }\end{array}$ & Hipermotoros & $\begin{array}{l}\text { Abnormális motoros } \\
\text { válasz } \\
\text { a) hipermotoros } \\
\text { b) parciális motoros }\end{array}$ & Hiperkinetikus \\
\hline & $\begin{array}{l}\text { Komplex motoros } \\
(10 \%) \\
\text { - kevésbé kifejezett } \\
\text { aszimmetrikus, } \\
\text { aszinkron törzs- és } \\
\text { végtagmozgás }\end{array}$ & $\begin{array}{l}\text { Axiális dystoniás } \\
\text { rohamok }\end{array}$ & Komplex motoros & $\begin{array}{l}\text { Affektív/emocionális } \\
\text { viselkedéses jelenség }\end{array}$ & $\begin{array}{l}\text { Axiális dystoniás } \\
\text { rohamok }\end{array}$ \\
\hline & & Dystoniás rohamok & & & Dystoniás rohamok \\
\hline & Kevert $(5,2 \%)$ & & Kevert & Kevert & Nem meghatározott \\
\hline $\begin{array}{l}\text { Pszichogén minor } \\
\text { motoros rohamok } \\
\text { vagy reszketés } \\
\text { (válaszkészség } \\
\text { elvesztése } 100 \% \text { ) }\end{array}$ & $\begin{array}{l}\text { Ritmusos motoros } \\
(42,6 \%) \\
\text { - a végtagokra és törzsre } \\
\text { kiterjedő szimmetrikus } \\
\text { és szinkron ritmusos } \\
\text { mozgás (tremor, } \\
\text { reszketés, rigor), } \\
\text { válaszkészség elvesztése } \\
83,8 \%\end{array}$ & $\begin{array}{l}\text { Hipokinetikus } \\
\text { (pauci-kinetikus) } \\
\text { rohamok } \\
\text { megtartott } \\
\text { válaszkészséggel } \\
\text { - nincsenek } \\
\text { törzsmozgások, a } \\
\text { mozgások jellemzően } \\
\text { az egyik végtagra vagy } \\
\text { a fejre kiterjedő } \\
\text { tremorra } \\
\text { korlátozódnak }\end{array}$ & Ritmusos motoros & & $\begin{array}{l}\text { Hipokinetikus } \\
\text { (pauci-kinetikus) } \\
\text { rohamok } \\
\text { megtartott } \\
\text { válaszkészséggel } \\
\text { vagy a nélkül }\end{array}$ \\
\hline \multirow[t]{2}{*}{$\begin{array}{l}\text { Pszichogén atónusos } \\
\text { (válaszkészség } \\
\text { elvesztése } 100 \% \text { ) }\end{array}$} & $\begin{array}{l}\text { Dialeptikus }(11,2 \%) \\
\text { - elhúzódó } \\
\text { mozgásszegény, olykor } \\
\text { hyperventilatióval (16\%) } \\
\text { és minden esetben a } \\
\text { válaszkészség } \\
\text { elvesztésével (100\%) } \\
\text { járó állapot }\end{array}$ & $\begin{array}{l}\text { Pseudosyncope } \\
\text { (hyperventilatio 0\%, } \\
\text { válaszkészség } \\
\text { elvesztése } 85 \% \text { ) }\end{array}$ & Dialeptikus & Dialeptikus & $\begin{array}{l}\text { Pseudosyncope } \\
\text { hyperventilatióval } \\
\text { vagy a nélkül } \\
\text { (hyperventilatio 18\%, } \\
\text { válaszkészség } \\
\text { elvesztése } 19 \% \text { ) }\end{array}$ \\
\hline & $\begin{array}{l}\text { Nem epilepsziás aura } \\
(23,6 \%) \\
\text { - nincs manifeszt tünet, } \\
\text { csak szubjektív érzet }\end{array}$ & & $\begin{array}{l}\text { Nem epilepsziás } \\
\text { aura }\end{array}$ & Nem epilepsziás aura & \\
\hline
\end{tabular}


esetén. Tipikusan PNER-re jellemző a roham hirtelen kezdete és vége, szemzárás és „pszeudoalvás” a roham kezdetekor, szakaszosan jelentkező, rendszertelen, aszimmetrikus és aszinkronos mozgások, oldalirányú fejrázás, opisthotonus testtartás, a medence tolómozgása, szem- és szájzárás, suttogás, dadogás, sírás a roham alatt vagy közvetlenül utána [22]. A PNER valószínűségét csökkentik, tehát kifejezetten az epilepsziás rohamokra jellemzők a praeictalis alvás, ritmusos és sztereotip mozgások, szemnyitás, illetve szemkimerevedés, vokalizáció, horkoló légzés, orális automatizmusok, nyelvharapás, inkontinencia, valamint a postictalis orrtörlés és köhögés, amelyek tipikusan temporalislebeny-epilepsziában figyelhetők meg [22].

A rohamok időtartamában szintén találunk különbséget [20]. Egy vizsgálatban a generalizált tónusos-clonusos rohamok átlagosan 50-92 másodpercig, míg a pszichogén rohamok 20-805 másodpercig tartottak [25]. Dikmen és mtsai vizsgálatában a pszichogén rohamok átlagidőtartama 241 másodperc volt, a betegek 40-45\%ánál pedig a 300 másodpercet is meghaladta [26]. A pszichogén rohamok szemiológiai jellemzői alapján történő osztályozására több kísérlet is született, amelyek során a domináns tüneteket vették alapul egy-egy alosztály megalkotására (1. táblázat) [15, 27-31]. A rohamok szubjektív megélésében ugyancsak találunk különbséget a PNER- és epilepsziás betegek között. Az epilepsziásokra a tudat, az akaratlagosság és a kontrollfunkciók elvesztésének intenzívebb megélése jellemző, és kevésbé képesek felidézni a roham alatt átélt élményeket, mint a PNER-betegek [20].

\section{Elektrofiziológiai eltérések}

A PNER-betegek vizsgálata során jellemzően normális ébrenléti EEG-tevékenység észlelhető, mind a roham előtt, alatt és azt követően [32]. Egyes esetekben leírható ictalis eltérés, amely a mozgásos mütermékek eredménye. Értékelhetetlen EEG-felvételek is születhetnek, ha a hipermotoros jelenségek olyan mértékű müterméket generálnak, hogy az teljesen elfedi a normális EEG-hátteret. Ezekben az esetekben azonban a mozgás végét követően a normális EEG-háttér azonnal visszaáll [32].

Beniczky és mtsai felszíni elektromiográfiás (EMG) vizsgálaton alapuló automatizált algoritmust fejlesztettek ki az epilepsziás és pszichogén rohamok differenciáldiagnosztikai felhasználására, amely saját vizsgálatukban 95\%-os pontossággal a video-EEG értékelésével egyező eredményt hozott [33]. Az eljárás a jövőben a videoEEG-nél lényegesen költséghatékonyabb alternatívát jelenthet a PNER diagnosztikájában.

\section{Neurohumorális faktorok}

A szérumprolaktinszint meghatározása mint kiegészítő vizsgálat segíthet a generalizált tónusos-clonusos rohamok és a PNER elkülönítésében. A roham kezdetétől számított 30 percen belül jelentkező prolaktinszintemelkedés ugyan az epilepszia diagnózisa mellett szól, de a változatlan prolaktinérték sem zárja ki egyértelmúen azt [22]. Hasonlóképpen, a szérum kreatin-foszfokináz szintjének emelkedése 12-15 órával a konvulzív jellegű rohamot követően közel 100\%-os biztonsággal erősíti meg az epilepszia diagnózisát, a normális postictalis értékek azonban nem zárják ki azt [34].

\section{Képalkotó vizsgálatok}

A strukturális és funkcionális képalkotó eljárások önmagukban szintén nem bírnak diagnosztikus értékkel, de támpontul szolgálhatnak a kivizsgálási folyamatban olyan esetekben, amikor a video-EEG önmagában nem elegendő a diagnózis felállításához.

A PNER-betegeket vizsgáló MRI-kutatásokban a dokumentált elváltozások a kisebb eltérésektől egészen a mesialis temporalis sclerosisig széles skálán mozognak [35]. Az eltérések ugyanakkor jellemzően nem jelentősek, és jóval gyakoribbak azoknál a betegeknél, akik egyszerre szenvednek epilepsziában és PNER-ben is $(77,2 \%)$, mint akik csak PNER-rel diagnosztizálhatók $(35,7 \%)[20]$.

A funkcionális képalkotó eljárások közül eddig a SPECT-vizsgálatot alkalmazták sikerrel a PNER diagnosztikájában. Az epilepsziás betegek ictalis és postictalis SPECT-felvételei között jelentősebb eltérések figyelhetők meg, szemben a PNER-betegekkel, akikre a fenti sajátosság nem jellemző [36]. Azokban az esetekben, amikor a PNER diagnózisát nem lehet egyértelmüen megállapítani video-EEG-vizsgálattal, kiegészítő SISCOM (Subtraction Ictal SPECT Co-registered to MRI) -analízis segíthet az epilepszia kizárásában [37].

\section{Etiológia}

A PNER hátterében mai ismereteink szerint nincs egyértelműen azonosítható organikus eltérés, bár a kórkép kialakulásában biológiai sérülékenység is feltételezhető, amelyre a betegek egy részénél kimutatható neurokognitív és strukturális, funkcionális agyi eltérések utalnak. A PNER etiológiájában - a magas pszichiátriai komorbiditás és az anamnézisben szereplő traumatikus életesemények gyakorisága miatt - kiemelt szerepet tulajdonítanak a pszichés faktoroknak. Fontos hangsúlyozni, hogy pszichológiai tényezők megléte ellenére a betegek nem szimulálnak.

\section{Pszichés trauma}

A PNER-betegek mintegy 70-90\%-a számol be korábbi súlyos traumatikus életeseményről [38]. A traumatizáció kisebb arányban van jelen férfiaknál és azoknál a betegeknél, akiknél a kórkép idősebb korban alakul ki [18]. A leggyakrabban előforduló trauma az élettörténetben a 
gyermekkori fizikai vagy szexuális abúzus [38]. A PNERbetegek az epilepsziásokkal összehasonlítva is szignifikánsan több szexuális és/vagy fizikai bántalmazásról számolnak be [39]. A fenti eredmények arra engednek következtetni, hogy a korai traumatizáció fontos prediszponáló tényezó lehet a PNER kialakulásában. A betegek körében a poszttraumás stressz zavar (PTSD) prevalenciája is szignifikánsan nagyobb, mint az egészséges populációban, ami felveti annak a lehetőségét is, hogy a PNER a PTSD egyik - speciális tünetekben megnyilvánuló - alcsoportja [2].

Más feltételezések szerint a PNER nem a gyermekkori bántalmazások közvetlen következménye, hanem mindkét probléma hátterében a családi rendszer diszfunkcionális múköóése áll [40]. Kutatások szerint a PNER-betegek nagyobb arányban számolnak be a családban előforduló pszichiátriai zavarokról, súlyos familiáris konfliktusokról, elégtelen támogatásról és hiperkritikusságról, mint az epilepsziások [40].

\section{Személyiség, megküzdés}

A személyiségvonásokat vizsgáló kutatások eredményei alapján nem sikerült felállítani egy olyan tipikus személyiségprofilt, ami a PNER-betegekre jellemző lenne. Ugyanakkor a betegek nagy része emelkedett értéket ért el az MMPI (Minnesota Multiphasic Personality Inventory) -teszt hisztéria, hipochondria, depresszió és szkizoidia skáláin [41]. A TCI (Temperament and Character Inventory) személyiségvizsgáló kérdőív alapján a PNERbetegek szorongóak, a bizonytalan kimenetelü helyzeteket nehezen tolerálják, a társas szférából érkező jutalmakra kevésbé fogékonyak, ugyanakkor magas teljesítményigénnyel, perfekcionizmussal és kontrolligénnyel jellemezhetők [38]. Klinikai vizsgálatok szerint a PNER-betegek 25-67\%-a felel meg valamilyen személyiségzavar kritériumainak [38, 42].

Továbbá a PNER-betegek kevésbé hatékony - elsősorban érzelemközpontú - megküzdési stratégiákat alkalmaznak, és kritikus helyzetben az emberekhez való bizalmatlan viszonyulás, az elzárkózás és a társas segítségnyújtás kerülése jellemző rájuk [38].

\section{Szomatizáció, disszociáció}

Kutatási eredmények szerint a PNER-betegek hajlamosabbak megmagyarázhatatlan testi tünetekkel reagálni az őket érő stresszkeltő életeseményekre [20]. Ahogy azt korábban láthattuk, a betegek MMPI-profiljában a hisztéria- és hipochondriaskálák emelkedett értéket vesznek fel [41]. Emellett az anamnézisükben nagy arányban találunk korábbi súlyos megbetegedést vagy balesetet, ami felerôsítheti a szomatizációs tendenciákat $[19,35]$. Szintén gyakoriak körükben az úgynevezett „funkcionális stresszbetegségek”, mint a krónikus fáradtság szindróma, tenziós fejfájás és irritábilis bél szindróma, amelyek- kel kapcsolatban szintén kiemelt szerepet tulajdonítanak a szomatizációnak [39].

A disszociáció olyan élmények körét írja le, amelyekre az észlelés, gondolkodás és az érzelmek tudati és emlékezeti integrációjának hiánya jellemző [43]. A disszociációs élmények nem feltétlenül tekinthetők patológiásnak, ugyanakkor előfordulásuk a PNER-betegek 90\%-át is érintheti, ami jóval felülmúlja a populációs átlagot [44]. Egyes elméletek szerint a disszociáció eredetileg adaptív válaszként lép fel traumatikus történésekkor, amelynek célja a trauma akut kedvezőtlen hatásainak csökkentése, hosszabb távon viszont mentális zavarok kialakulásának kedvez [5]. A disszociatív tünetképzés a komorbid - traumával összefüggő - pszichiátriai zavarral diagnosztizált PNER-betegek körében fordul elő a legnagyobb arányban [45].

\section{Kognitín deficit}

Neuropszichológiai vizsgálatok során a PNER-betegek összteljesítménye jellemzően nem marad el az átlagtól. Ugyanakkor több kognitív tartomány (memória, kognitív rugalmasság, tervezés, információfeldolgozás sebessége) mentén is rosszabbul teljesítenek, mint a hasonló korú, iskolázottságú személyek $[20,38]$. Reuber és mtsai vizsgálatában a PNER-betegek 60,6\%-a legalább 1,5 szórással átlag alatti eredményt ért el legalább egy kognitív funkció mentén [20]. Többen felhívták a figyelmet arra is, hogy a gyermekkori tanulási zavar a PNER egyik kockázati tényezője lehet $[19,46]$. Ugyanakkor a legtöbb szerző nem tudott azonosítani egy tipikusan PNER-re jellemző neurokognitív profilt.

$\mathrm{Az}$ eredmények kapcsán olyan értelmezések is születtek, amelyek a betegek kisebb motivációjában vagy szimulációs tendenciákban keresték a választ [47]. Más feltételezések szerint a traumával összefüggó zavarokra jellemző figyelmi és koncentrációs problémáknak tudható be a rosszabb teljesítmény [48]. Utóbbit támogatja az a tény, hogy a korábbi bántalmazásról beszámoló és a komorbid PTSD-vel diagnosztizált PNER-betegek jellemzően rosszabb teljesítményt érnek el a memóriafunkciókat vizsgáló neuropszichológiai teszteken [49].

\section{Organicitás}

A PNER kialakulásában neurobiológiai faktorok is közrejátszanak, amelyre a betegek egy részénél talált neuropszichológiai, strukturális és funkcionális agyi eltérések és a magas arányban előforduló korábbi fejtrauma utal $[20,35]$.

Labate és mtsai a corticalis vastagságot - köztük a szürkeállomány-térfogatot - vizsgálták voxelalapú morfometriával, amely az egészséges kontrollcsoporthoz viszonyítva a PNER-betegek körében szignifikáns corticalis elvékonyodást jelzett a jobb agyfélteke primer motoros és premotoros, valamint a kisagy bilateralis területein [50]. Az eredmények azonban fenntartásokkal kezelen- 
dők, mivel szinte az összes vizsgálati személyt depresszióval is diagnosztizálták; hasonló strukturális eltéréseket pedig depresszióban is kimutattak [5l].

Újabb kutatások fókuszában az fMRI/EEG alapú funkcionális és a diffúziós MRI-alapú strukturális agyi hálózatok vizsgálata áll. A kutatási eredményekből arra következtethetünk, hogy egyes specifikus funkciók (figyelem, érzelemszabályozás, végrehajtó funkciók, akaratlagos izommozgások) ellátásáért felelős agyi hálózatokon belül a normálistól eltérő strukturális és funkcionális szerveződés jellemző a PNER-betegekre [52].

Arthuis és mtsai F-fluoro-dezoxi-glükózzal végzett PET-vizsgálata során PNER-betegeknél az érzelemszabályozás (anterior cingularis kéreg), az énérzet és a környezet tudatosításáért (jobb inferior parietalis kéreg) felelős agyi régiókban hipometabolizmust azonosítottak [53]. Perez és mtsai feltételezik, hogy a krónikus stressz hatására bekövetkező neuroplasztikus változások a medialis prefrontalis kéreg és az amygdala területén hozzájárulhatnak azoknak a specifikus neuralis köröket érintó rendellenességeknek a kialakulásához, amelyeket a képalkotó vizsgálatok feltártak [54].

Tekintettel arra, hogy a fenti eltérések csak a betegek egy részénél vannak jelen, valószínúleg heterogén csoportot képeznek a szerint, hogy milyen formában és mértékben vannak hatással a PNER kialakulására és fennmaradására.

\section{A PNER patogenezisének integratín modellje}

Ahogy a fentiekben láthattuk, számos olyan faktort sikerült azonosítani, amelyek részt vehetnek a PNER patogenezisében; a folyamat modellálására pedig több kísérlet is született $[2,55]$.

Prigatano modelljében az egyik faktor egy olyan kognitív-emocionális sajátosság, amely az egyént a disszociációs tendenciákra hajlamosítja kritikus élethelyzetekben, a másik faktor pedig a stressz adekvát kezelését, feldolgozását érintő idegrendszeri sérülékenység [55]. A két faktor interakciójának eredménye lehet a szenzomotoros funkciók és a tudatosság integritásának felbomlása.

Bodde és mtsai egy hierarchikus modellt írtak le, amelyben az egyes faktorok mint prediszponáló, precipitáló és prolongáló tényezők vesznek részt [2].

1. Pszichológiai etiológia: Azok a faktorok, amelyek következményeként alakulhat ki a PNER (például: traumatikus életesemények, szexuális vagy fizikai abúzus).

2. Vulnerabilitás: Azok a rizikótényezők, amelyek hajlamossá teszik az egyént a pszichoszomatikus tünetképzésre (például: személyiségvonások, organikus vagy neurokognitív eltérések).

3. Alakító tényezők: Azok a faktorok, amelyek a pszichoszomatikus tünetek speciális, görcsrohamokban való megnyilvánulásáért felelősek (például: korábbi epilepsziás rohamok vagy epilepsziás családtag).

4. Kiváltó tényezők: Azok a faktorok, amelyek aktuálisan provokálhatnak rohamot. Idetartozik az elsődleges betegségelőny, a fizikai vagy pszichés megterhelés, düh, szorongás, illetve azok a pszichológiai mechanizmusok, amelyek hatására az érzelmi válaszok testi tünetekben manifesztálódnak (például: disszociáció, szomatizáció).

5. Prolongáló faktorok: Azok a tényezők, amelyek a rohamok hosszú távú fennmaradásához járulnak hozzá (például: kor, megküzdési stratégiák, másodlagos betegségelőny). A modell egyes elemei interakcióban állnak egymással, és a hierarchia több szintjén is megjelenhetnek, így a családi problémák a kórkép kialakulásában és fennmaradásában egyaránt részt vehetnek.

\section{Terápia}

A pszichogén rohamok kezelésének első lépése a helyes diagnózis felállítása után az antiepileptikus kezelés felfüggesztése, illetve - epilepsziabetegség egyidejű fennállása esetén - racionalizálása, és a kórképpel kapcsolatos információátadás a betegek és hozzátartozóik részére [22]. A megfelelő orvosi kommunikáció fontos eleme a PNER terápiájának, mivel a sok esetben évekig tartó - téves diagnózison alapuló - kezelés megingathatja a betegek gyógyulásba vetett hitét, ami tünetváltáshoz vagy a terápia megszakításához vezethet [56]. Több szerző beszámolt róla, hogy a helyes diagnózis megfelelő közlése és az alapszintü pszichoedukáció sok esetben további terápiás beavatkozások hiányában is a tünetek spontán remissziójához vezetett $[56,57]$.

A PNER farmako-, illetve pszichoterápiás kezelésének megtervezésekor a következő szempontokat célszerü szem előtt tartani. Mindenekelőtt széles körü pszichiátriai kivizsgálásnak kell alávetni a betegeket, amelynek célja a differenciáldiagnosztika mellett a komorbid pszichiátriai zavarok és a PNER kialakulásában, fennmaradásában részt vevő faktorok azonosítása [1].

\section{Pszichoterápia}

A pszichoterápiás beavatkozások közül a legtöbb publikáció a kognitív viselkedésterápiás (CBT) módszerek hatékonyságáról született, amelyeket már évtizedek óta alkalmaznak sikerrel számos más szomatoform zavar kezelésében is $[2,58]$. A kognitív-viselkedés intervenciók strukturált, időkorlátos terápiás keretek között zajlanak, és a hangsúlyt elsősorban a rohamokat előidéző érzelmi állapotok felismerésére, a rohamok megszüntetését elősegítő készségek (például: relaxáció) elsajátítására és a stresszkeltő életeseményekkel való hatékonyabb megküzdésre helyezik $[58,59]$. A CBT két utánkövetéses vizsgálatban is hatékonyabbnak bizonyult, mint a standard - elsősorban farmakoterápián alapuló - pszichiátriai kezelés [58, 59].

Egyéb pszichoterápiás módszerek tekintetében kevesebb randomizált, kontrollált vizsgálat született, de biztató eredményeket publikáltak a pszichodinamikus [60], csoportterápiás [61], valamint mindfulness alapú terápi- 
ák [62] hatékonyságáról. A családterápia pedig elsősorban gyermekek esetében javasolt, ahol a tünetképzésben kiemelt szerepe van a familiáris eredetű stresszoroknak [2].

\section{Farmakoterápia}

A PNER-betegek farmakoterápiája során elsőként az antiepileptikus kezelést szükséges felfüggeszteni abban az esetben, ha teljes bizonyossággal kizárható az epilepszia [63]. Amennyiben mindkét kórkép fennáll, az antiepileptikumok számának vagy dózisának optimalizálása és párhuzamosan egyéb farmako- vagy pszichoterápiás intervenciók megkezdése javasolt.

A PNER gyógyszeres terápiája alapvetően a szomatoform zavarok és a komorbid pszichiátriai kórképek kezelési protokolljának felel meg [63]. A PNER akut tüneteinek gyógyszeres kezelése - a rosszullétek leállítását célzó erőteljes szedációt leszámítva - nem ismert [2]. A hosszabb távú farmakoterápiás medikáció - köztük a triciklikus antidepresszívumok, szelektív szerotoninvisszavételt gátló (SSRI) készítmények, dopaminreceptor-agonisták, béta-blokkolók, benzodiazepinszármazékok - hatékonyságáról ugyancsak kevés adat áll rendelkezésre, és ezek nagy része anekdotikus beszámolókból, esettanulmányokból származik [63]. A PNERrel komorbid pszichiátriai zavarok kezelésében az SSRImedikáció a legelterjedtebb $[1,63]$.

\section{Prognózis}

Farias és mtsai vizsgálatában a helyes diagnózis megállapítását követő 24 órában a PNER-betegek szignifikáns javulást mutattak a rohamok gyakoriságát illetően, 2 hónappal később pedig 38\%-uk vallotta tünetmentesnek magát [57]. Kuyk és mtsai kutatásukban arról számolnak be, hogy az ambuláns pszichoterápiát követően a betegek $80 \%$-ánál a rohamok gyakorisága jelentősen csökkent, 50\%-uk pedig teljesen tünetmentessé vált [64].

A hosszú távú prognózis sokkal kevésbé biztató. Az egy évet meghaladó utánkövetéses vizsgálatok eredményei szerint a betegek $60-80 \%$-a visszaesést mutat [57, 65]. A PNER-rel küzdő gyermekek és serdülők utánkövetéses vizsgálatai során ugyanakkor lényegesen pozitívabb eredményeket találtak [66]. Wyllie és mtsai vizsgálatában a hároméves utánkövetés során a fiatalkorú betegek 81\%-a maradt tünetmentes [65]. Gudmundsson és mtsai féléves utánkövetés során $59 \%$-os, egy év után 63\%-os teljes gyógyulási arányt regisztráltak a 8-15 éves korú betegcsoportban [67].

A prognózis több tényező függvénye. Pozitív prognosztikai értéke van a fiatalabb életkornak és a nói nemnek, a magasabb intelligenciahányadosnak és szocioökonómiai státusznak, az egészséges premorbid személyiségnek, az önálló életvitelnek, a kisebb erősségű és rövidebb ideje fennálló rohamoknak, a rohamokat kiváltó, egyértelmúen azonosítható traumának és a korábbi antiepileptikus medikáció hiányának [56].

\section{Következtetések}

A PNER nehezen meghatározható, ugyanakkor a neurológiai praxisban gyakran elóforduló kórkép, amely az epilepsziacentrumok betegforgalmának jelentős részét teszi ki. A betegség - komplexitása miatt - nagy kihívást jelent mind a differenciáldiagnosztika, mind a terápia tekintetében. A PNER etiológiája nem teljesen tisztázott, jelenlegi ismereteink birtokában feltételezhető, hogy a pszichológiai és organikus faktorok az egyes betegeknél eltérő súllyal vesznek részt a kórkép kialakulásában és fennmaradásában. A prognosztika szempontjából kiemelten fontos a PNER integratív - neuropszichiátriai és pszichoterápiás megfontolásokat egyaránt figyelembe vevő - megközelítése.

Anyagi támogatás: A közlemény megírása anyagi támogatásban nem részesült.

Szerzői munkamegosztás: Sz. B.: Témafelvetés, irodalomkutatás, a kézirat megszövegezése. H. Z.: Irodalomkutatás, a kézirat megszövegezése, szakmai értékelése. A cikk végleges változatát mindkét szerző elolvasta és jóváhagyta.

Érdekeltségek: A szerzőknek nincsenek érdekeltségeik.

\section{Irodalom}

[1] LaFrance, W. C. Jr., Devinsky, O.: The treatment of nonepileptic seizures: historical perspectives and future directions. Epilepsia, 2004, 45(Suppl. 2), 15-21.

[2] Bodde, N. M., Brooks, J. L., Baker, G. A., et al.: Psychogenic nonepileptic seizures - definition, etiology, treatment and prognostic issues: a critical review. Seizure, 2009, 18(8), 543-553.

[3] Dickinson, P., Looper, K. J.: Psychogenic nonepileptic seizures: a current overview. Epilepsia, 2012, 53(10), 1679-1689.

[4] Ellenberger, H. F.: The discovery of the unconscious; the history and evolution of dynamic psychiatry. Basic Books, New York, 1970.

[5] Van der Kolk, B. A., Fisler, R.: Dissociation and the fragmentary nature of traumatic memories: overview and exploratory study. J. Trauma Stress, 1995, 8(4), 505-525.

[6] American Psychiatric Association: Diagnostic and Statistical Manual of Mental Disorders, Fifth Edition: DSM-5. American Psychiatric Association Publishing, Washington, 2013.

[7] World Health Organization: The ICD-10 Classification of Mental and Behavioural Disorders. Clinical descriptions and diagnostic guidelines. 10th revision. WHO, Geneva, 1992.

[8] Schmutz, M.: Dissociative seizures - a critical review and perspective. Epilepsy Behav., 2013, 29(3), 449-456.

[9] Asadi-Pooya, A. A., Sperling, M. R.: Epidemiology of psychogenic nonepileptic seizures. Epilepsy Behav., 2015, 46, 60-65.

[10] Sigurdardottir, K. R., Olafsson, E.: Incidence of psychogenic seizures in adults: a population-based study in Iceland. Epilepsia, $1998,39(7), 749-752$. 
[11] Duncan, R., Razvi, S., Mulhern, S.: Newly presenting psychogenic nonepileptic seizures: incidence, population characteristics, and early outcome from a prospective audit of a first seizure clinic. Epilepsy Behav., 2011, 20(2), 308-311.

[12] Benbadis, S. R., Allen-Hauser, W.: An estimate of the prevalence of psychogenic non-epileptic seizures. Seizure, 2000, 9(4), 280281.

[13] Martin, R., Burneo, J. G., Prasad, A., et al.: Frequency of epilepsy in patients with psychogenic seizures monitored by videoEEG. Neurology, 2003, 61(12), 1791-1792.

[14] Marchetti, R. L., Kurcgant, D., Gallucci-Neto, J., et al.: Epilepsy in patients with psychogenic non-epileptic seizures. Arq. Neuropsiquiatr., 2010, 68(2), 168-173.

[15] Szabó, L., Siegler, Z., Zubek, L., et al.: A detailed semiologic analysis of childhood psychogenic nonepileptic seizures. Epilepsia, 2012, 53(3), 565-570.

[16] Asadi-Pooya, A. A., Emami, M.: Juvenile and adult-onset psychogenic non-epileptic seizures. Clin. Neurol. Neurosurg., 2013, 115(9), 1697-1700.

[17] Rosenbaum, M.: Psychogenic seizures - why women? Psychosomatics, 2000, 41(2), 147-149.

[18] Oto, M., Conway, P., McGonigal, A., et al.: Gender differences in psychogenic non-epileptic seizures. Seizure, 2005, 14(1), 33-39.

[19] Seneviratne, U., Briggs, B., Lowenstern, D., et al.: The spectrum of psychogenic non-epileptic seizures and comorbidities seen in an epilepsy monitoring unit. J. Clin. Neurosci., 2011, 18(3), 361-363.

[20] Reuber, M.: Are psychogenic non-epileptic seizures an expression of neurologic pathology? In: Kanner, A. M., Schachter, S. C. (eds.): Psychiatric controversies in epilepsy. Academic Press, San Diego, 2008.

[21] Varela, H., Benbadis, S. R.: Episodic neurologic symptoms. In: Schoenberg, M. R., Scott, J. G. (eds.): The little black book of neuropsychology. A syndrome-based approach. Springer Science \& Business Media, New York, 2011.

[22] LaFrance, W. C. Jr: Psychogenic nonepileptic seizures. Curr. Opin. Neurol., 2008, 21(2), 195-201.

[23] Benbadis, S. R.: Provocative techniques should be used for the diagnosis of psychogenic nonepileptic seizures. Epilepsy Behav., 2009, 15(2), 106-109.

[24] Avbersek, A., Sisodiya, S.: Does the primary literature provide support for clinical signs used to distinguish psychogenic nonepileptic seizures from epileptic seizures? J. Neurol. Neurosurg. Psychiatry, 2010, 81(7), 719-725.

[25] Gates, J. R., Ramani, V., Whalen, S., et al.: Ictal characteristics of pseudoseizures. Arch. Neurol., 1985, 42(12), 1183-1187.

[26] Dikmen, P. Y., Unlusoy Acar, Z., Gurses, C.: Clinical events in psychogenic non-epileptic seizures based on semiological seizure classification. Neurol. Res., 2013, 35(10), 1070-1075.

[27] Gröppel, G., Kapitany, T., Baumgartner, C.: Cluster analysis of clinical seizure semiology of psychogenic nonepileptic seizures. Epilepsia, 2000, 41(5), 610-614.

[28] Seneviratne, U., Reutens, D., D'Souza, W.: Stereotypy of psychogenic nonepileptic seizures: insights from video-EEG monitoring. Epilepsia, 2010, 51(7), 1159-1168.

[29] Hubsch, C., Baumann, C., Hingray, C., et al.: Clinical classification of psychogenic non-epileptic seizures based on video-EEG analysis and automatic clustering. J. Neurol. Neurosurg. Psychiatry, 2011, 82(9), 955-960.

[30] Dhiman, V., Sinha, S., Rawat, V. S., et al.: Semiological characteristics of adults with psychogenic nonepileptic seizures (PNESs): an attempt towards a new classification. Epilepsy Behav., 2013, 27(3), 427-432.

[31] Wadwekar, V., Nair, P. P., Murgai, A., et al.: Semiologic classification of psychogenic non epileptic seizures (PNES) based on video EEG analysis: do we need new classification systems? Seizure, 2014, 23(3), 222-226.
[32] Gedzelman, E. R., LaRoche, S. M.: Long-term video EEG monitoring for diagnosis of psychogenic nonepileptic seizures. Neuropsychiatr. Dis. Treat., 2014, 10, 1979-1986.

[33] Beniczky, S., Conradsen, I., Moldovan, M., et al.: Automated differentiation between epileptic and nonepileptic convulsive seizures. Ann. Neurol., 2015, 77(2), 348-351.

[34] Brigo, F., Igwe, S. C., Erro, R., et al.: Postictal serum creatine kinase for the differential diagnosis of epileptic seizures and psychogenic non-epileptic seizures: a systematic review. J. Neurol., 2015, 262(2), 251-257.

[35] LaFrance, W. C. Jr., Deluca, M., Machan, J. T., et al.: Traumatic brain injury and psychogenic nonepileptic seizures yield worse outcomes. Epilepsia, 2013, 54(4), 718-725.

[36] Cuthill, F. M., Espie, C. A.: Sensitivity and specificity of procedures for the differential diagnosis of epileptic and non-epileptic seizures: a systematic review. Seizure, 2005, 14(5), 293-303.

[37] Neiman, E. S., Noe, K. H., Drazkowski, J. F., et al.: Utility of subtraction ictal SPECT when video-EEG fails to distinguish atypical psychogenic and epileptic seizures. Epilepsy Behav., 2009, 15(2), 208-212.

[38] Bodde, N. M., van der Kruijs, S. J., Ijff, D. M., et al.: Subgroup classification in patients with psychogenic non-epileptic seizures. Epilepsy Behav., 2013, 26(3), 279-289.

[39] Dixit, R., Popescu, A., Bagić, A., et al.: Medical comorbidities in patients with psychogenic nonepileptic spells (PNES) referred for video-EEG monitoring. Epilepsy Behav., 2013, 28(2), 137140.

[40] Salmon, P., Al-Marzooqi, S. M., Baker, G.: Childhood family dysfunction and associated abuse in patients with nonepileptic seizures: towards a causal model. Psychosom. Med., 2003, 65(4), 695-700

[41] Owczarek, K.: Somatisation indexes as differential factors in psychogenic pseudoepileptic and epileptic seizures. Seizure, 2003, $12(3), 178-181$

[42] Alsaadi, T. M., Marquez, A. V.: Psychogenic nonepileptic seizures. Am. Fam. Physician, 2005, 72(5), 849-856.

[43] Bernstein, E. M., Putnam, F. W.: Development, reliability, and validity of a dissociation scale. J. Nerv. Ment. Dis., 1986, 174(12), 727-735.

[44] Bowman, E. S., Markand, O. N.: Psychodynamics and psychiatric diagnoses of pseudoseizure subjects. Am. J. Psychiatry, 1996, 153(1), 57-63

[45] Baslet, G., Roiko, A., Prensky, E.: Heterogeneity in psychogenic nonepileptic seizures: understanding the role of psychiatric and neurological factors. Epilepsy Behav., 2010, 17(2), 236-241.

[46] Duncan, R, Oto, M.: Psychogenic nonepileptic seizures in patients with learning disability: comparison with patients with no learning disability. Epilepsy Behav., 2008, 12(1), 183-186.

[47] Drane, D. L., Williamson, D. J., Stroup, E. S., et al.: Cognitive impairment is not equal in patients with epileptic and psychogenic nonepileptic seizures. Epilepsia, 2006, 47(11), 18791886.

[48] Van der Kolk, B., van der Hart, O., Marmar, C.: Dissociation and information processing in posttraumatic stress disorder. In: van der Kolk, B. A., McFarlane, A. C., Weisaeth, L. (eds.): Traumatic stress: the effects of overwhelming experience on mind, body and society. Guildford Press, New York, 1996.

[49] Myers, L., Zeng, R., Perrine, K., et al.: Cognitive differences between patients who have psychogenic nonepileptic seizures (PNESs) and posttraumatic stress disorder (PTSD) and patients who have PNESs without PTSD. Epilepsy Behav., 2014, 37, 82-86.

[50] Labate, A., Cerasa, A., Mula, M., et al.: Neuroanatomic correlates of psychogenic nonepileptic seizures: a cortical thickness and VBM study. Epilepsia, 2012, 53(2), 377-385.

[51] DeLange, F. P., Toni, I., Roelofs, K., et al.: Altered connectivity between prefrontal and sensorimotor cortex in conversion paralysis. Neuropsychologia, 2010, 48(6), 1782-1788. 
[52] Ding, J. R., An, D., Liao, W., et al.: Altered functional and structural connectivity networks in psychogenic non-epileptic seizures. PLoS ONE, 2013, 8(5), e63850.

[53] Arthuis, M., Micouland-Franchi, J. A., Bartolomei, F., et al.: Resting cortical PET metabolic changes in psychogenic non-epileptic seizures (PNES). J. Neurol. Neurosurg. Psychiatry, 2015, 86(10), 1106-1112.

[54] Perez, D. L., Dworetzky, B. A., Dickerson, B. C., et al.: An integrative neurocircuit perspective on psychogenic nonepileptic seizures and functional movement disorders: neural functional unawareness. Clin. EEG Neurosci., 2015, 46(1), 4-15.

[55] Prigatano, G. P., Stonnington, C. M., Fisher, R. S., et al.: Psychological factors in the genesis and management of nonepileptic seizures: clinical observations. Epilepsy Behav., 2002, 3(4), 343349.

[56] Reuber, M., Elger, C. E.: Psychogenic nonepileptic seizures: review and update. Epilepsy Behav., 2003, 4(3), 205-216.

[57] Farias, S. T., Thieman, C., Alsaadi, T. M.: Psychogenic nonepileptic seizures: acute change in event frequency after presentation of the diagnosis. Epilepsy Behav., 2003, 4(4), 424-429.

[58] LaFrance, W. C. Jr., Baird, G. L., Barry, J. J., et al.: Multicenter pilot treatment trial for psychogenic nonepileptic seizures: a randomized clinical trial. JAMA Psychiatry, 2014, 71(9), 997-1005

[59] Goldstein, L. H., Chalder, T., Chigwedere, C., et al.: Cognitivebehavioral therapy for psychogenic nonepileptic seizures: a pilot RCT. Neurology, 2010, 74(24), 1986-1994.

[60] Kalogjera-Sackellares, D.: Psychodynamics and psychotherapy of pseudoseizures. Crown House Publishing, Carmarthen, 2004.
[61] Barry, J. J., Wittenberg, D., Bullock, K. D., et al.: Group therapy for patients with psychogenic nonepileptic seizures: a pilot study. Epilepsy Behav., 2008, 13(4), 624-629.

[62] Baslet, G., Dworetzky, B., Perez, D. L., et al.: Treatment of psychogenic nonepileptic seizures: updated review and findings from a mindfulness-based intervention case series. Clin. EEG Neurosci., 2015, 46(1), 54-64.

[63] LaFrance, W. C. Jr., Blumer, D.: Pharmacological treatments for psychogenic nonepileptic seizures. In: Schachter, S. C., LaFrance, W. C. Jr. (eds.): Gates and Rowan's nonepileptic seizures. Cambridge University Press, New York, 2010.

[64] Kuyk, J., Siffels, M. C., Bakvis, P., et al.: Psychological treatment of patients with psychogenic non-epileptic seizures: an outcome study. Seizure, 2008, 17(7), 595-603.

[65] Wyllie, E., Friedman, D., Lüders, H., et al.: Outcome of psychogenic seizures in children and adolescents compared with adults. Neurology, 1991, 41(5), 742-744.

[66] Reilly, C., Menlove, L., Fenton, V., et al.: Psychogenic nonepileptic seizures in children: a review. Epilepsia, 2013, 54(10), 17151724.

[67] Gudmundsson, O., Prendergast, M., Foreman, D., et al.: Outcome of pseudoseizures in children and adolescents: a 6-year symptom survival analysis. Dev. Med. Child Neurol., 2001, 43(8), 547551.

(Szita Bernadett, Budapest, Baross u. 27., 1088 e-mail: szitabernadett@t-online.hu)

\section{MEG HÍ Vó}

\section{A Szent János Kórház és Észak-budai Egyesített Kórházak Tudományos Bizottsága tisztelettel meghívja az érdeklődőket a következő tudományos ülésére.}

\section{Téma: Aktuális kérdések a véráram fertőzésekkel, a glaucoma kezeléssel kapcsolatban Időpont: 2016. május 26. (csütörtök) 14 óra \\ Helyszín: Szent János Kórház Auditóriuma - 1125 Budapest, Diós árok 1-3.}

Üléselnök: Prof. Dr. Jánosi András

\section{Előadások}

Dr. Székely Éva (Jahn Ferenc Dél-pesti Kórház és Rendelőintézet): S. aureus bacteriaemiák jelentősége 20 perc

Dr. Rákay Erzsébet (Szent János Kórház), Dr. Szilágyi Emese (Országos Tisztifőorvosi Hivatal):

Perifériás érkatéterekkel összefüggő fertőzések megelőzése

20 perc

Dr. Szigeti Zoltán: Glaucoma, a trükkös betegség

10 perc

Dr. Csaba Gábor: Glaucoma változások a klasszifikációban

10 perc

Dr. Kirják Henriett: Új vizsgálómódszerek a glaucomában

10 perc

Dr. Csoma Éva: A glaucoma kezelése

10 perc

Dr. Gombos Katalin: Keringés és a szem

10 perc

\section{BÜFÉ}

Minden érdeklődőt szeretettel várunk! 